\title{
Oeconomia Suffocato: The Origins of Antipathy Toward Free Enterprise Among Catholic Intelligentsia ${ }^{1}$
}

Joseph J. Hyde

Loyola University New Orleans, United States

e-mail: jihyde@my.loyno.edu

Walter E. Block

Loyola University New Orleans, United States

e-mail: wblock@loyno.edu

\begin{abstract}
:
What is the source of the antipathy of Catholic intellectuals toward free markets? That is the issue addressed in the present paper. We see the antecedents of this viewpoint of theirs in terms of secular humanism, Marxism and mistaken views of morality and economics. One of the explanations for this phenomenon are the teachings of St Augustine. He greatly distrusted the City of Man, seeing it as anarchic and chaotic. In contrast, his City of God is more orderly, but far removed from the hurly burly of free enterprise. Another source of the rejection of capitalism on the part of Catholic intellectuals is liberation theology, which is Marxism minus the atheism of that doctrine. Both economic and cultural Marxism have played a role in the alienation of such intellectuals from the tenets of laissez faire capitalism. Are there any counter currents? Yes, the School of Salamanca, which has been all but forgotten in this community.

Keywords: Catholicism, free enterprise, liberation theology, Marxism.
\end{abstract}

\section{Introduction}

Why is there is a yearning among the intelligentsia of the Catholic $\mathrm{Church}^{2}$ for the promotion of its ideals through the state? This is especially puzzling in that Catholicism is a religion that values independent human agency, a characteristic associated with free enterprise [47]. 
True moral authority, can only be attained by setting an example or by voluntary choice. It simply cannot be accomplished through the coercive mechanism of the state. Coercion deprives an act of its voluntary nature, the essential ingredient that makes it moral in the first place. This is in contrast to that essential gift of God toward mankind: "agency" [61] (Gen. 2.16-17). Free will has been ordained to man since the beginning; free will cast man out of the Garden of Eden and brought death to the world. Furthermore, free will allowed Christ to choose death upon the cross as an example of sacrifice for the sins of the world. However, in its present state, Catholic social teaching denies the fundamental right of choice - enshrined by God - in favor of imposing morality through the mechanism of the state. This is especially true of freedom of choice in the marketplace. There, the behavior of free and consenting adults is treated as something that must be managed for the greater moral good. ${ }^{3}$ This is not a new problem but rather an old one: Catholicism and state control have been intertwined since Constantine the Great made Christianity the official religion of the Empire in the early fourth century of the common era $[15$, p. 1]. This union with power had been in place for over 1,500 years and, with the exception of very few individuals and groups within Catholicism - Pope Leo XIII and the school of Salamanca, for example - human freedom in the marketplace has been perceived as contrary to the interests of the Church. ${ }^{4}$

The Church's union with power is not the only factor that results from this desire to control freedom in the marketplace. The teachings of St Augustine - in particular, his idea of utmost good make a significant contribution to the Church's anti market stance. For Augustine, order through justice in the City of God is in a constant struggle with chaos and disorder in the City of Man. ${ }^{5}$ These views have profound and residual effects on church policy even to this day, which leads to an anti-free-will worldview. Where freedom is allowed, it must necessarily be ordered for the greater good - including markets. This does not, however, explain the present condition among Catholic institutions today. To understand that, we must consider two more necessary ingredients: the first is the Protestant Reformation, which undermined the Church's power to impose its will politically. This led to the Scientific Revolution and ultimately government justified by social contract in contrast with natural law and divine will. In short, the undermining of Church authority, when this institution became divorced from the state, because of the Reformation, led to an even greater assertion of control in many respects.

The second ingredient of the present condition is the rise of Marxism as a moral authoritative theory regarding mankind's ultimate destiny; it became a secular cousin to Augustine's City of God, but on earth. With this comes the fusion of Marxism and Christianity into pseudo-Marxist Christianity among the Catholic intelligentsia. Liberation theology, the primary form of Marxist Christianity, is not only what is referenced here. ${ }^{6}$ Rather, we refer to the phenomenon of a secular worldview that ascribes a moral historicist destiny to mankind grafted onto Catholic teaching originally meant to be determined via free will. Marxism, because it aims at a utopian moral end, becomes the perfect mechanism for Catholicism to justify partnership with the state, a religion that also seeks a moral utopian end through order and justice. Thus, a dialectic occurs where two seemingly opposing views at first glance Catholicism and Marxism - have much more in common than would appear based on first appearances. These similarities become very apparent when a common antagonist is identified: capitalism. The free market prevents the ordering for which both systems strive by manifesting its own spontaneous order ${ }^{7}$ [41, p. 395]. This makes attractive and practical the union of Catholicism and Marxism into a beneficial alliance against a capitalist common enemy. This alliance ultimately is meant to create the better world to which both Marxism and Catholicism aspire.

In section II we discuss The Bible, Catholicism and Free Enterprise. Section III is given over to a consideration of Rome and Augustine, while section IV deals with the Reformation and section V with Marxism. We conclude in section VI. 


\section{The Bible, Catholicism and Free Enterprise}

The idea that the state should be used to constrain individuals in an effort to bring about a more moral vision of the world has been refuted again and again in biblical passages, even in cases where "excess and greed" are enunciated upon specifically and used in parables to illustrate immoral behavior. The parable of the rich man and the beggar Lazarus stands out as a story with particular weight concerning this issue [61] (Luk. 16.19-25). In this parable, Lazarus is afflicted with sores and starvation while the rich man is finely clothed and lives well day-to-day. Ultimately, after Lazarus longed for the crumbs from the rich man's table and is rejected, he is thus doomed to death from starvation. In time, the rich man also dies. While Lazarus is carried off to heaven by angels into the bosom of Abraham, the rich man is consigned to the fires of hell. What is important in this example from a free enterprise perspective is that nowhere in the parable did Lazarus appeal to the Roman authority to constrain the immoral greed of the rich man. Furthermore, Abraham responds to the rich man in hell saying "Child, remember that during your lifetime you received your good things, and Lazarus in like manner evil things; but now he is comforted here and you are in agony" [61] (Luk. 16.25). The rich man was allowed to do what he did to make himself rich and the beggar starve. The entire responsibility of the rich man for his transgressions and inhumanity was left to his own free will because of his agency. No matter the level of greed and cruelty exercised, he was still free to do it, but held accountable only in the next life.

Let us introduce a modicum of economic analysis to the proceedings at this point. There is a strong implication that the reason the poor man is poor is due to the fact that the rich man is rich. That is the latter came to his wealth by exploiting the former. But posit that the wealthy man came to his earnings honestly; that is, he was not a crony capitalist, gaining through government largesse, but was rather a product of laissez faire capitalism. Then, the only way he could become affluent would be by enriching the poor. Thus, due to his actions, the poor man had more largesse than otherwise would have been the case. The Bill Gates' of the world need not "give back" anything whatsoever to the poor to compensate for their aggrandizement. No, to the contrary, in putting together his fortune in the first place, if he did it compatibly with libertarian principles, he has already "given" to the poor, by enriching them. That he refuses to do even more for them, for example by refusing to donate to them through charity, should not be allowed to obfuscate the fact that he has increased their economic status while doing so on his own account. ${ }^{8}$

In a similar vein is the parable of John the Baptist and his response to the people and the publicans. The people are appealing to John, who ask of him "What then should we do" in reference to being good Christians. They were given the answer to donate coats and food if they had them to those who had not [61] (Luk. 3.10-11). When the tax collectors asked the same, the response was similar: "Collect no more than the amount prescribed for you" ([61] Luk. 3.12-13). Finally he told the soldiers, "Do not extort money from anyone by threats or false accusation, and be satisfied with your wages" [61] (Luk. 3.14).

The goal here is not to argue that the bible refutes the legitimacy of the state: it does not. The previous situations necessarily imply, along with many others, that the relationship between an individual and his faith is something distinctly separate from the state, with the former taking precedence over the latter. If they were not separate, why not encourage the tax collectors to take as much from those with wealth and re-distribute to those with little money, in order to act in a Christian manner? Instead, they are told to take the minimum for a reason: the state is not responsible for imposing Christian charity. In the case of the soldier, it required a partial separation of his purpose imposed by the state because of Christian conversion "Do not extort money from anyone by threats" [61] (Luk. 3.14). One of the primary roles of a soldier is the symbolism he provides as an enforcement of government programs through threat of violence. Here the threat of force is morally challenged with regard to the collection of money. This could reference individual extortion but more likely 
overbearing taxes and threats of collection enforcement by soldiers since the passage immediately follows guidance for tax collectors. Christianity is an individualist and altruist ethos that will be tested and challenged in the trials of this world, but ultimately the ability to surmount those challenges and trials is left to the individual. This is why, in parable after parable, the Roman authority was never appealed to impose Christian morality on society. ${ }^{9}$ These passages infer a Christian support of free will and, subsequently, free enterprise. At minimum, the ability to be greedy grants individuals autonomy of moral decision-making and, at maximum, allows and encourages those who would choose to feed Lazarus at the dinner table the opportunity to do so.

Further support for laissez faire capitalism can be explicitly derived from the papal encyclical Rerum Novarum. Released by Pope Leo XIII, this document addresses many specific issues regarding the conceptual practice of free markets, most notably a fierce support of property rights. This view is quite clear: "every man has by nature the right to possess property as his own" [26, p. 6] and also "the fact that God has given the earth for the use and enjoyment of the whole human race can in no way be a bar to the owning of private property" [26, p. 8], as well as "private ownership is in accordance with the law of nature" [26, p. 9]. These statements do not indicate an explicit approval of complete economic freedom but certainly a tacit sympathy for this system. Furthermore, the statement "the limits of private possession have been left to be fixed by man's own industry, and by the laws of individual races" $[26$, p. 8] grants at minimum the individual's right of sovereignty over how property is used at least equal to that of the state. Looking at the rest of the document and its repudiation of forced state collectivism, it is clear that the individual mandate supersedes that of the government. ${ }^{10}$

There is also the school of Salamanca, an enlightenment school of Catholic philosophy spread across Spain and Portugal, which consistently recognized the value of private property and free enterprise in improving the welfare of the community in accordance with Christian teaching. One of the great scholastics of this school, Luis de Molina, is expressly recognized as the "upholder of free will, according to whom the grace of God could only become efficient by the consent of man", this is in accordance with the individualist altruist approach of Christian teaching [21, p. 46]. The school of Salamanca also fostered capitalist concepts such as subjective valuation, which necessarily requires a free market apparatus to facilitate price fluctuations.

In contrast is value based on use, promoted by St. Augustine [21, p. 25]. Here, a good has value based on its use; for example, shoes are shoes whether they are shiny or of better quality, because value is derived from the fact that you walk in them, so it is implied there is a "just" or "moral" monetary value for that use. When one subscribes to a theory of use value, it implies that prices which exceed the value of the objects' perceived use are immoral and must be rejected as greedy. However, this runs contrary to powerfully influential philosophers such as St Augustine. There is a significant strain of thought within Catholicism of an individualism that promotes and requires freedom. This is especially true in the marketplace, not merely as a moral litmus test on human actions which will come under judgement in the afterlife but to promote human flourishing at present. People must be free to acquire wealth, which alone cures poverty both for the rich and all of society. As well it offers the means by which the wealthy are able to be charitable. The question that now arises is why, among Catholic intellectuals today, is appealing to the state to impose morality on the market held in higher esteem than an individual's right to choose moral market action for himself, guided by Catholic principles or not? The origin of this edifice is composed of two foundations: Rome, and St. Augustine.

\section{In the Beginning There Was Rome, and Then Augustine}

In the 4th century B.C.E, the Roman emperor Constantine wedded Christianity to the Roman Empire, consecrating it as the official religion of the Empire and of its subjects. This union dramatically altered Christianity and the way it was spread forever after. With this union of power came the ability to simply graft the morality of the Christian doctrine onto the fallible world of men through law. The state 
became the sword and shield of God; no longer was it the responsibility of the individual to choose the Christian path of love - love and compassion would be mandated from on high. In theory, the church was always supreme to the government. In practical reality, God was brought down from the heavens and embodied into the Roman authority. According to [15], after Rome became a Christian Empire "laws were passed mitigating many of the evils of slavery, condemned criminals were not to be forced to become gladiators, the condition of prisoners was materially improved, a peasant's plough-oxen could not be distrained for debt, the practice of branding prisoners on the face was stopped, children were given new protection" [31]. The egalitarian nature of the church structure before the Roman union dissipated, giving way to the hierarchical structuring of the Roman authority.

That same structure today is a remnant of the union with Rome. No longer would the spreading of the faith be exclusively voluntary. Rather, violence could now be sanctioned to spread the gospel, just as it had been sanctioned to expand territory under the pagan emperors. The church was superior to the state before Constantine's conversion, but with his conversion Christianity now subordinated the power structure that had once persecuted it. The leaders who this relationship attracted ultimately changed from men such as the apostles to the Borgias. A religion that does not inherently value earthly power, yet comes to possess tremendous amounts of it, as Christianity did, necessarily attracts those who value the power associated with the faith rather than the faith in and of itself. ${ }^{11}$ The Roman period set the stage for normalizing the use of state power to impose Christian morality. So as Christianity moved into the feudal age of Europe, a philosophy for its role and purpose, especially its use of power, developed in the vacuum left by the collapse of Rome. The philosophical giant who inscribed the tabula rasa of Catholic thought is Augustine of Hippo, a reformed libertine, whose ideas persist and permeate Roman Catholic teaching to this day.

Augustine is most famous as the early developer of Just War Theory, ${ }^{12}$ a set of guidelines dictating which actions justify war and also how Christians should wage it, both in terms of levels of violence employed and appropriate restraint in conflict. For the conceptual understanding of regulating moral action in the market through the state, we must look specifically to Augustine's concept of utmost good in the realms of both man and God. For Augustine there are two realms, which exist in opposition to each other. The first is the City of Man, founded by Cain who slew his brother Abel. The City of Man is home to fallen angels and man. It is a paragon of chaos. The second realm is the City of God, which exists in perfection, filled with those loyal to God, a paragon of order that provides perfect justice. The City of God, made just and perfect by order, opposes the City of Man. In a famous passage regarding the state, Augustine says "Set justice aside then, and what are kingdoms but fair thievish purchases" [1, p. 115]. An unjust state that acts against the divine law of Christian teaching necessarily acts against the interests of true justice and order willed by God. While Augustine never explicitly advocates for a state-driven City of God on earth, it is clear that his worldview is encouraging of it ["Every family then being part of the city, every beginning having relation to it follows evidently that the families peace adheres unto the city's, that is, the orderly command and obedience in the family have real reference to the orderly rule and subjection in the city. So that the father of the family should fetch his instructions from the cities government, whereby he may regulate the peace of his estate by that of the common"] [1, p. 254]. In practical terms, this is useful for the Roman Catholic Church and justifies imposing Christian moral standards through state action. This is necessary for Augustine because free will is the origin of sin and evil, as it voluntarily embraces the passions and turns us away from the will of god [2, pp. 138-142]. This view of the world as corrupted and in need of re-ordering because of free will, combined with the union of Christianity and the Roman state, led to the violent conversions and draconian mandate of Christian belief structures in medieval Europe. Also, in equally detrimental fashion, it divorced the philosophical view of the intelligentsia away from free will and human choice, in favor of a coercive mandate.

This confluence of Rome and Augustine paved the way for justifiable state involvement among the Catholic intelligentsia into "unjust transactions" [44, p. 21]. However, it was not acted upon the 
way it is in the modern sense until the late 19th century. The reasons for this are many. However, the primary cause of disinterest upon comparison to the present is that such control and action offered no real benefits. Feudalism offered minimal wealth to control in contrast to the present. From Christian Rome to the enlightenment, the church possessed tremendous power and influenced directly or indirectly many European armies. At times when the state, with sanction of the church wanted wealth, it simply took it as needed by force. A famous example is the seizure of all the territory bequeathed to The Knights Templar military order in France. The king of that country, under sanction of the pope, seized Templar territory and property, executing their leader after torturing many into falsely confessing crimes [60, p. 9]. There was more to lose than gain, whether in control or cost, by promoting the regulation of the small amount of free enterprise that existed under feudalism compared to what would exist under the productive capacities unleashed by capitalism. Another reason state regulation of economic behavior was not pursued more vociferously is that enforcement during such periods was weak at best and there were simply other issues of more importance to garner the attention of the Church and its subordinate states. Those same governments were in constant conflict for control with each other and influence in the church itself.

\section{The Reformation}

The Scientific Revolution, driven by the Renaissance and the Protestant Reformation, altered the dynamic of the Catholic Church's relationship to the state, which had been in place for over 1500 years. The most significant of these events was the Reformation, which rejected the theological authority of the Catholic Church and subsequently its constraints on freedom of conscience. This severely undermined its rule in Europe. By the mid seventeenth century Protestantism was growing in many parts of Europe [42, p. 81]. Protestantism returned individual autonomy to Christian practice and destroyed, though not instantaneously, the duality of a single church and state power structure in Europe. However, the Reformation did not destroy the idea of just government in accordance with divine law and the will of God, which remained among the Catholic intelligentsia. The Reformation lost Catholicism the instrument through which it imposed its will and a large portion of its influence in worldly affairs in Europe.

The rise of capitalism in the seventeenth and eighteenth centuries also brought a new power structure to the world: economics. Material yearnings became ever more influential and important over spiritual ones, as centuries of divine authority under feudalism not only failed to provide material contentment and stem starvation and suffering but also rejected individual liberty. Capitalism began more and more to provide both; for the first time in history it was not only the elite who could live well but also more and more the masses. Furthermore, freedom and individual autonomy allowed interests to be pursued that did not put God first but instead worldly pleasures, whether pursuits of the mind or the "corrupting" pleasures of materialism.

With the Catholic power structure in retreat a response to capitalism began developing, a response the Catholic intelligentsia would graft onto itself just as Christianity had grafted itself to Rome: Marxism. In theory, Marxism rejects theology, but religion does not - necessarily reject Marxism. Marx, when referring to religion, famously stated: "It is the opium of the people" [29, p. 4]. However, while Marxism rejected religion, it embraced a critical view of capitalism, as did Catholicism among the intelligentsia. While the Marxist rejects religion and would have difficulty accepting religious teaching as part of his philosophy, the theologian has no such encumbrance. There is a mutual willing embrace, in both schools of thought, of harsh criticisms regarding capitalism, especially when this system is viewed as a force that "paves the way for a particular type of tyranny" and is the cause of "hardships, unjust practices, and fratricidal conflicts that persist to this day" [44, p. 26]. Furthermore, free enterprise ${ }^{13}$ embodied a new power structure, which for both Marxists and Catholic intelligentsia ${ }^{14}$ was anathema. Entrepreneurs, businessmen, profit seekers, hucksters rose up on their hind legs without 
any by-your-leave of anyone previously in control. This was intolerable to the powers that used to be, or, wanted to be. Control of the means of production is encouraged as long as "it is to be rational and fruitful, any socialization of the means of production must take this argument into consideration" [43, p. 15]. The argument concerns ensuring labor is prioritized over capital and man is aware he is working for himself [43, p. 15]. This is a view reciprocated between Marxism and the Church, that man is not working for himself under laissez faire but is really just a slave to materialism. To save him from this fate, production and private property must be socialized to realize a more just end.

Rerum Novarum explicitly railed against socialism. In referring to advocates of that system, the document states: "They are, moreover, emphatically unjust, for they would rob the lawful possessor, distort the functions of the state, and create utter confusion in the community" [26, p. 4]. However, this encyclical, which is only in part opposed to the adoption of socialist tendencies as a means to justice, cannot on its own counter 1500 years of historical precedent of the role between church and state and doctrinal revisionism. While the Church, in its capacity acting as the state, never explicitly acted as a socialist government, the precedent opposes the ideas espoused in Rerum Novarum. The adoption of Marxist thinking into Catholic social thought is clearly evidenced when comparing and contrasting Marx with Catholic writings: "Thus, under the leadership of justice and in the company of charity, created goods should flow fairly to all. All other rights, whatever they may be, including the rights of property and free trade are subordinated to this principle... as the church fathers tell us, the right of private property may never be exercised to the detriment of the common good" [44, p. 22]. Compare this to language in the Communist Manifesto: "Private property must, therefore, be abolished and in its place must come the common utilization of all instruments of production and the distribution of all products according to common agreement" [20, p. 14]. The evolution of the view of property rights from Rerum Novarum to Populorum Progressio is just one example. These illustrations conform to a trend seen across all of the papal encyclicals dealing with the economy.

\section{Marxism}

Even the meaning of a biblical parable has been distorted and misused by the adoption of Marxist thought into Catholic social teaching. In Populorum Progressio appears a quote from St. Ambrose: "You are not making a gift of what is yours to the poor man, but you are giving him back what is his. You have been appropriating things that are for the common use of everyone. The earth belongs to everyone, not to the rich" $[44$, p. 9]. This passage is meant to reinforce the Marxist position on private property and the idea of greed in its use, but the quote is St Ambrose's commentary on the tragedy of Naboth, who owned a vineyard he refused to sell to King Ahab, who after Naboth's refusal simply seized his property. The story is as follows: Upon return to his palace the King's wife Jezebel inquires about the King's mood and promptly promises to acquire Naboth's vineyard for her husband, since he refused to sell. This is done by false accusation and mock trial, after which Naboth is executed and the King takes his land. The irony in the use of this parable in Populorum Progressio is that the parable itself speaks to the wickedness and immorality of the state violating the property rights of Naboth by both taking his life and his vineyard. Subsequently, the prophet Elijah visits King Ahab and promises judgement by God for such a violation. The commentary on greed by St Ambrose is in reference to the murder and theft by King Ahab of Naboth's private property. Once this commentary is filtered through the Marxist lens and adopted by the Catholic intelligentsia it is used to deconstruct the very rights it was meant to enshrine.

\section{Conclusion and Implications}

The reciprocation and encouragement of anti-market sentiment between Roman Catholicism and Marxism remains strong among the Catholic intelligentsia today. The foundation of such bonds is 
partially laid in the philosophy of Augustine, where the utmost good is justice through order. This union cemented the idea of an ordered and just world with its attainability through state action. Furthermore, the Protestant Reformation and rise of capitalism had a profound effect on the alliance of Catholicism with Marxism. As the reformation undermined the power structure of Catholicism in governments across Europe and around the globe, capitalism diluted the Catholic Church's influence with the common man. What the Catholic power structures in Feudal Europe failed to provide, higher standards of living and the freedom to pursue those standards, Capitalism and Protestantism encouraged. This weakened a long-held influential power structure in Europe. Pope Francis inveighs against "the worship of the ancient golden calf" and "the idolatry of money and the dictatorship of an impersonal economy lacking a truly human purpose" or capitalism. This system effectively destroyed much of the Church's influence in the West [25, p. 4]. Thus Marxists and Catholic scholars found themselves to be strange bedfellows. Both are defined by what they became opposed to: the free market. While mea culpas have taken place between Catholicism and Protestantism [17, p. 1], antipathy for laissez faire remains strong. While Marxists could not graft Catholicism onto their ethos, no such boundary existed for Catholic social teaching. Up to the present, the prism through which capitalism is viewed by the Catholic cognoscenti is a Marxist one. It can even be argued that biblical teaching is filtered through the lens of Marxism, as we see in the interpretation of parables such as Naboth clearly being obfuscated to serve a desired Marxist viewpoint. The circumstances of the Naboth parable when accurately read are in fact in favor of private property and opposed to the abolition of it promoted by Marxism.

The implications for Catholic social thought in the future are uncertain. The period of human freedom, especially that of economic freedom, has been impactful. This preserves the staying power of capitalism. It is unlikely that any outside influences on the Catholic intelligentsia will undermine its pseudo-alliance with Marxism. It is likely too deeply embedded for that to occur. A reformation in thought would be most effective only from within. Where the Catholics today have the most influence in government, in particular in Latin America, the failure of states such as Venezuela under the Maduro regime may sway the Church away from Marxism. However, the Church views its own ideas as a middle way between the free market and Marxism and separates itself from the results of secular Marxism in Latin America [43, p. 14]. This view gives the Church the ability to claim successes where they exist and divorce itself from state failures.

The false association of capitalism with colonialism is also a barrier to free enterprise becoming accepted among theologians, especially in Latin America. The system of mercantilism drove colonial expansion, and capitalism was a response arguing against colonial enterprises and for voluntary trade [47, p. 641]. If such a distinction could be made clear then it is possible the tide would turn in favor of economic freedom in Catholic intellectual circles. Finally, concerning the Catholic Intelligentsia, the argument is the following: The fusion of Marxist economic theory with Catholicism, ${ }^{15}$ illuminates the antipathy of Catholic teaching toward free enterprise even into the present day. It is an antipathy that is not only unwarranted but does great harm to devout Catholics. It is no accident, for example, that the South American and PIGS (Portugal, Ireland, Greece, Spain) countries most under the sway of the Catholic Church do not do as well, economically, as do those not so encumbered. ${ }^{16}$

\section{References}

1. Augustine. The City of God = De Civitate Dei, London: Dent, 1945.

2. Augustine. The Problem of Free Choice $=$ De Libero Arbitrio, Transl. by M. Pontifex, Westminster: Md., Newman, 1955.

3. Barnett, W. Human Nature, the Bishops, and the American Economy, Loyola Law Review 33, 203, 1987-1988.

4. Block, W. Focus on Economics and the Canadian Bishops, Vancouver: The Fraser Institute, 1983. 
5. Block, W. Neglect of the Marketplace: The Questionable Economics of America's Bishops, Notre Dame Journal of Law, Ethics and Public Policy, 2, 1, 1985, pp. 125-160.

6. Block, W. Liberation Theology and the Economy, Grail: An Ecumenical Journal, I, 3, September, 1985, pp. 75-85.

7. Block, W. The U.S. Bishops and Their Critics: An Economic and Ethical Perspective, Vancouver: The Fraser Institute, 1986.

8. Block, W. Economics of the Canadian Bishops, Contemporary Policy Issues, VI, 1, January, 1988, pp. 56-68.

9. Block, W. Discussion, The Preferential Option for the Poor, R. J. Neuhaus (ed.), Grand Rapids, Mich.: William E. Eerdmans Publishing Co., 1988, pp. 87-114.

10. Block, W. Hayek's Road to Serfdom, Journal of Libertarian Studies: An Interdisciplinary Review, 12, 2, Fall, 1996, pp. 327-350.

11. Block, W. E. Religion and Libertarianism: Ayn Rand was wrong, June 18, 2008.

12. Block, W. E. Ayn Rand, Religion and Libertarianism, Journal of Ayn Rand Studies, 11, 1, 21, July 2011, pp. 63-79.

13. Block, W. \& and G. Yeatts. The Economics and Ethics of Land Reform: A Critique of the Pontifical Council for Justice and Peace's 'Toward a Better Distribution of Land: The Challenge of Agrarian Reform,' Journal of Natural Resources and Environmental Law, 15, 1, 1999-2000, pp. 37-69. 14. Booth, P. (ed.). Catholic social teaching and the market economy, London: Institute of Economic Affairs, 2007.

15. Brookes, E. H. The conversion of Constantine and the establishment, Theoria: A Journal of Social and Political Theory, 35, 1970, pp. 31-34.

16. Carden, A. Christian Ethics, Formal Institutions, and Economic Growth, American Review of Political Economy, 5(1) 2007, pp. 34-53.

17. Casilli, R. Why the Pope Just Asked Protestants for Forgiveness, Newsweek, Reuters, 17 May 2016.

18. Chafuen, A. A. Christians for Freedom: Late Scholastic Economics, San Francisco: Ignatius Press, 1986.

19. Chafuen, A. A. Faith and Liberty: The Economic Thought of the Late Scholastics, Studies in Ethics and Economics, Lanham: Lexington, 2003.

20. Engels, F. Principles of Communism. www.marxists.org N.p., 1999. Web. 02 May 2017. A draft document by Engels published posthumously. First Published: 1914, Eduard Bernstein in the German Social Democratic Party's Vorwärts.

21. Grice-Hutchinson, M. The School of Salamanca: Readings in Spanish Monetary Theory, 15441605, Auburn, Ala.: Ludwig Von Mises Institute, 2009 [1952].

22. Gwartney, J., R. Lawson \& W. E. Block. Economic Freedom of the World, 1975-1995, Vancouver, B.C. Canada: the Fraser Institute, 1996.

23. Hayek, F. A. The Road To Serfdom, Chicago: The University of Chicago Press, 1944.

24. Hill, F. Bill Gates Has Done More To Help People Than Mother Teresa, December 8, 2013.http://www.telemachusleaps.com/2013/12/bill-gates-has-done-more-to-help-people.html

25. Huddleston, T. Jr. 5 Times Pope Francis Talked About Money, www.fortune.com. Fortune, 15 Sept. 2015. Web. 8 May 2017.

26. Leo XIII. Rerum Novarum, 26 Mar. 1967. 2 May. 2017. Web.

27. Lewis, P. Who's better? Bill Gates or Mother Teresa? February 3, 2017. http://www.wnd.com/2017/02/whos-better-bill-gates-or-mother-teresa/\#GmYMfdHx5SFA5D6z.99

28. Light, Ch. \& W. E. Block. Christianity, the Free Market, and Libertarianism, Studia Humana, Vol. 6, No. 4, 2017, pp. 34-44.

29. Marx, K. A Contribution to the Critique of Hegel's Philosophy of Right 1844. DeutschFranzösische Jahrbücher (1844): n. pag. Marxists.org. 7 Feb. 1844. Web. 8 May 2017. 
30. Martin, R. The Two Cities in Augustine's Political Philosophy, Journal of the History of Ideas 33.2, 1972, pp. 195-216.

31. McElroy, W. Can a Principled Libertarian Go to War? July 6, 2011.

32. Nash, R. H. (ed.). Liberation Theology, Milford, Michigan: Mott Media, Inc., 1984.

33. North, G. Tools of Dominion: The Case Laws of Exodus, Tyler, TX: Institute for Christian Economics, 1990.

34. North, G. Millenialism and the Progressive Movement, The Journal of Libertarian Studies, 12, 1, 1996, pp. 121-142.

35. Novak, M. The Spirit of Democratic Capitalism, Simon \& Schuster: New York, 1978.

36. Novak, M. The Denigration of Capitalism, Washington D. C.: American Enterprise Institute for Public Policy, 1979.

37. Novak, M. (ed.). Capitalism and Socialism, Washington D. C.: American Institute for Public Policy Research, 1979.

38. Novak, M. (ed.). Liberation South, Liberation North, Washington D. C.: American Enterprise Institute for Public Policy, 1981.

39. Novak, M. The Liberal Society as Liberation Theology, Notre Dame Journal of Law, Ethics and Public Policy, V. 2, 1, 1985.

40. Nozick, R. Anarchy, State and Utopia, New York: Basic Books, 1974.

41. Ogus, A. I. Law and Spontaneous Order: Hayek's Contribution to Legal Theory, Journal of Law and Society, 16.4, 1989.

42. Parker, G. Success And Failure During The First Century Of The Reformation, Past and Present, 136.1, 1992, pp. 43-82.

43. John Paul II. Laborem Exercens, 15 Sept. 1981. 2 May. 2017. Web.

44. Paul IV. Populorum Progressio, 26 Mar. 1967. 2 May. 2017. Web.

45. Ritenour, S. Foundations of Economics: A Christian View, Wipf and Stock: Publishers, 2010.

46. Rockwell, Jr. \& H. Llewellyn. Free Market Economists: 400 Years Ago, The Freeman: Ideas on Liberty, 45, 9, 1995.

47. Rothbard, M. N. Economic Controversies, Auburn, Alabama: Ludwig Von Mises Institute, 2011.

48. Rothbard, M. N. New Light on the Prehistory of the Austrian School, In. E. G. Dolan (ed.), The Foundations of Modern Austrian Economics, Kansas City: Sheed \& Ward, Inc., 1976, pp. 52-74.

49. Rothbard. M. N. An Austrian Perspective on the History of Economic Thought, London: Edward Elgar, 1995.

50. Rothbard, M. N. Just War, In J. V. Denson (ed.), The Costs of War: America's Pyrrhic Victories, New Brunswick, N. J.: Transaction Publishers, 1997.

51. Schall, J. V. Liberation Theology, San Francisco: Ignatius Press, 1982.

52. Schall, J. V. Religion, Wealth and Poverty, Vancouver: The Fraser Institute, 1989.

53. Schansberg, E. D. Turn Neither to the Right Nor to the Left, Christian Life and Public Policy Series, Alertness Books, 2003.

54. Sebast, E. Mother Teresa or Bill Gates? May 23, 2016; https://www.linkedin.com/pulse/motherteresa-bill-gates-eric-sebast

55. Sirico, R. A. Moral Base for Liberty, Irvington-on-Hudson, N.Y.: Foundation for Economic Education, 1996.

56. Sirico, R. A. Capitalism, Morality and Markets, London: Institute for Economic Affairs, 2001.

57. Huerta de Soto, J. New Light on the Prehistory of the Theory of Banking and the School of Salamanca, The Review of Austrian Economics, 9, 2, 1996, pp. 59-81.

58. Huerta de Soto, J. Juan De Mariana: The Influence of the Spanish Scholastics, 2004, https://www.scribd.com/document/328171967/Juan-de-Mariana-the-Influence-of-the-SpanishScholastics. 
59. Huerta de Soto, J. Biography of Juan de Mariana: The Influence of the Spanish Scholastics (15361624), August 1, 2007, https://mises.org/library/biography-juan-de-mariana-influence-spanishscholastics-1536-1624.

60. The Editors of Encyclopædia Britannica. Templar Religious Military Order, Encyclopædia Britannica, Encyclopædia Britannica, Inc., n.d. Web. 8 May 2017.

61. The Holy Bible: Containing the Old and New Testaments with the Apocryphal/Deuterocanonical Books, New York: Oxford University Press, 1989.

62. Vance, L. M. Christianity and War and Other Essays Against the Warfare State, Pensacola Florida: Vance Publications, 2008, $2^{\text {nd }}$ edition.

63. Vance, L. Is Libertarianism Compatible With Religion? March 15, 2011,

http://libertarianchristians.com/2011/03/16/is-libertarianism-compatible-with-religion/

64. Watner, C. 'All Mankind is One': The Libertarian Tradition in Sixteenth Century Spain, The Journal of Libertarian Studies, 8, 2, 1987, pp. 293-310.

65. Whitehead, R, Walter E. Block, \& P. Tinsley. Christian Landlords and the Free Exercise Clause: Sinners Need Not Apply, Oklahoma City University Law Review, 33, 1, 2008, pp. 115-150.

66. Woods, T. E. Jr. Catholic Social Teaching and Economic Law: An Unresolved Tension, 2002, http://www.mises.org/asc/2002/asc8-woods.pdf.

67. Woods, T. E. Jr. Morality and Economic Law: Toward a Reconciliation, 2004, http://www.mises.org/fullstory.asp?control=1481

68. Woods, T. E. Jr. The Church and the Market: A Catholic Defense of the Free Economy, Lanham, Md.: Rowman and Littlefield, 2005.

69. Woods, T. E. Jr. An Open Letter to the Catholic Community in Behalf of Ron Paul, November 21, 2007, http://www.lewrockwell.com/woods/woods83.html

70. Woods, T. E. Jr. The Attractiveness of Austrian Economics, July 21, 2013, https://www.youtube.com/watch?v=DStLhWMRERM

\section{Notes}

1. The authors of the present paper wish to thank Bradley Warshauer, Katelyn Fecteau and Alfred Jackson for comments on an earlier draft, which greatly improved it. However, the usual disclaimer applies; we, alone, are fully responsible for all remaining errors.

2. Exceptions within the Jesuit Order include Fr. James Sadowsky, SJ, Fr. James Schall, SJ and Fr. Frank Hilton, SJ.

3. [40, p. 163] calls for the allowance of "capitalist acts between consenting adults".

4. On the school of Salamanca see: [14], [16], [18], [19], [21], [45], [46], [48], [49], [55], [57], [58], [59], [63], [64], [66], [67], [68], [70].

5. [30] discusses several different interpretations regarding the City of God vs the City of Man.

6. Liberation theology substitutes Catholic theism for the atheism of Marxism, but is otherwise indistinguishable from it. See on this: [3], [4], [5], [6], [7], [8], [9], [13], [18], [19], [32], [39], [51], [52], [53], [63], [66], [68], [69].

7. From [41]: "Knowledge of the innumerable facts which make up the human condition is necessarily widely dispersed and fragmentary. Individuals making decisions about courses of action can at best rely on limited information normally pertaining to localized environments. Interaction and co-operation with others are, of course, essential, but this does not imply a planned or directive form of social organization. The spontaneous order which emerges is self- generating or endogenous: it is not deliberately brought about and has no explicit purpose; rather it results from the instinctive adoption of certain (often unformulated) rules. This idea of unplanned order is exemplified by the development of human language but also by animal life, for example in the insect societies of bees, ants, and termites."

8. For the claim that Bill Gates, via MicroSoft, not his later charitable giving, has done more to alleviate poverty than Mother Theresa, see [24], [27], [54].

9. In many parables the presumption of free will appears to supercede the act in and of itself regarding morality, it is not a moral or immoral act if one is not actively choosing to commit it.

10. Rerum Novarum seems to be an outlier in its promotion of free will and private property compared to other encyclicals. This may be because the successor to Leo XIII, Pius X, had modernists purged from the church as he himself was a 
traditionalist. Possibly, based on the shift in language over such a short period in the encyclicals, pro free enterprise thinkers in Leo's circle of influence may have been shown the door under the Pius administration of the church as suspected or de facto modernists.

11. A good summation of the implications of concentrated power can be found in [23], specifically chapter 10 "Why the Worst get on Top." For a critique, albeit on other grounds, see [10].

12. For a libertarian perspective on this concept, see [31], [50], [62], [63].

13. For a defense of this system from a theological point of view, see [11], [12], [18], [19], [28], [65], [68].

14. Of course, not all Catholic scholars would agree. Here are some exceptions: [14], [16], [18], [19], [45], [46], [55], [56], [57], [63], [64], [66], [67], [68]. Also see [33], [34].

15. Explained supra.

16. [22], [35], [36], [37], [38]. 